\title{
Renal Cell Carcinoma with Clear Cell Papillary Features: Perspectives of a Differential Diagnosis
}

\author{
Áron Somorácz ${ }^{1}$ - Levente Kuthi ${ }^{2} \cdot$ Tamás Micsik $^{3}$ - Alex Jenei ${ }^{2} \cdot$ Adrienn Hajdu $^{2} \cdot$ Brigitta Vrabély $^{3}$. \\ Erzsébet Rásó ${ }^{1} \cdot$ Zoltán Sápi $^{3} \cdot$ Zoltán Bajory $^{4} \cdot$ Janina Kulka $^{1} \cdot$ Béla Iványi $^{2}$
}

Received: 22 May 2019 / Accepted: 1 October 2019 / Published online: 26 October 2019

(C) The Author(s) 2019

\begin{abstract}
Thirty-one cases of low-grade renal cell carcinoma (RCC) with clear cells and tubulopapillary/papillary architecture were analyzed retrospectively with immunohistochemical and genetic markers to gain more experience with the differential diagnosis of such cases. All samples coexpressed CK7 and CA9; the TFE3 or TFEB reactions were negative; the CD10 and the AMACR stainings were negative in 27 cases and 30 cases, respectively. The FISH assays for papillary RCC, available in 27 cases, and deletion of chromosome $3 p$, available in 29 cases, gave negative results. The results for $3 p$ deletion, $V H L$ gene mutation or $V H L$ gene promoter region hypermethylation testing, along with the diffuse CD10-positivity in 2 cases confirmed 21 cases as clear cell papillary RCC (CCPRCC; CK7+, CA9+; no 3p loss, no VHL abnormality) and 10 cases as clear cell RCC (CCRCC; CK7+, CA9+; no $3 p$ loss, VHL abnormality mutation/hypermethylation present). In CCPRCCs, the representative growth pattern was branching tubulo-acinar, commonly accompanied by cyst formation. The linear nuclear arrangement or cup-shaped staining of CA9 did not necessarily indicate CCPRCC, and the absence of these did not exclude the diagnosis of CCPPRC. One tumor infiltrated the renal sinus; the others exhibited pT1 stage; and metastatic outcome was not recorded. The CCRCC cases were in pT1 stage; 6 exhibited cup-shaped staining of CA9, and 1 displayed lymph node metastasis at the time of surgery. Distant metastatic disease was not observed. In summary, the VHL abnormalities distinguished the subset of CCRCC with diffuse CK7positivity and no $3 p$ loss from cases of CCPRCC.
\end{abstract}

Keywords Clear cell carcinoma $\cdot$ Clear cell papillary carcinoma $\cdot$ Cytokeratin 7-positivity $\cdot$ Differential diagnosis $\cdot V H L$ gene

\section{Introduction}

Clear cell papillary renal cell carcinoma (CCPRCC) is an infrequent subset of RCC [1,2]. Although CCPRCC shares

Áron Somorácz and Levente Kuthi contributed equally.

Electronic supplementary material The online version of this article (https://doi.org/10.1007/s12253-019-00757-3) contains supplementary material, which is available to authorized users.

Áron Somorácz

somoracz14@gmail.com

1 2nd Department of Pathology, Semmelweis University, Üllői út 93, Budapest H-1091, Hungary

2 Department of Pathology, University of Szeged, Szeged, Hungary

3 1st Department of Pathology and Experimental Cancer Research, Semmelweis University, Budapest, Hungary

4 Department of Urology, University of Szeged, Szeged, Hungary histopathogical features with clear cell RCC (CCRCC), papillary RCC and Xp11.2 translocation RCC, its immunohistochemical coexpression of cytokeratin 7 (CK7) and carbonic anhydrase 9 (CA9), and negativity for CD10, alpha-methylCoA racemase (AMACR), and TFE3 usually clarifies the diagnosis [3-7]. The renal angiomyoadenomatous tumor (RAT) is now regarded as being in the spectrum of CCPRCC [8-10]. Genetically, CCPRCCs lack chromosome 3p deletion or VHL gene mutation or $V H L$ promoter hypermethylation, the hallmarks of CCRCC, and have no loss of chromosome $\mathrm{Y}$ or gain of chromosome 7 and 17, the hallmarks of papillary RCC [2-4, 11-13].

In surgical pathology practice, the separation of CCPRCCs from CCRCCs can pose certain difficulties. The distinction is crucial, because CCPRCCs have a very limited potential for metastasis (fatal outcome has been reported only in two patients out of 400 [14]), whereas in low-grade CCRCCs distant metastases can occur several years after nephrectomy. To learn more about the differential diagnosis of low-grade RCCs with 
CCPRCC features, a series of such tumors were subjected to a retrospective immunohistochemical analysis, applying CK7, CA9, CD10, AMACR, TFEB and TFE3 immunostainings, and the immunophenotypes were correlated with the results of genetic markers for CCRCC or papillary RCC.

\section{Materials and Methods}

\section{Case Selection and Review Process}

This study was conducted with the permission of the Medical Research Council (17489-4/2017/EKU). The hematoxylin and eosin-stained slides of 2326 consecutive RCC samples were reexamined for clear cell papillary RCC-like tumors, including low-grade nuclei, the presence of any degree of tubulopapillary growth pattern of tumor cells with clear cytoplasm, linear arrangement of nuclei away from the basal membrane, along with the presence of a leiomyomatous stroma. Demographical and clinical data were collected from the database management systems of Semmelweis University and University of Szeged.

\section{Tissue Microarray and Immunohistochemical Reactions}

Tissue microarray blocks were prepared for immunohistochemistry with TMA Master (3DHISTECH) applying a $2 \mathrm{~mm}$ core diameter. One to four representative cores were then punched out from the donor blocks. Immunohistochemical staining for CA9, CK7, CD10, AMACR, TFEB and TFE3 were performed (see the dilutions and sources in Supplementary Table 1). The epitope retrieval was performed for each antibody according to the manufacturer's recommendations. The reactions were conducted using Autostainer (Dako). Afterwards, slides were evaluated microscopically by estimating the proportion (\%) of immunopositive cells. Staining in over $50 \%$ of the tumor cells, in 10 to $50 \%$ of tumor cells, or in less than $10 \%$ of the tumor cells, was interpreted as diffusely or focally positive or negative, respectively.

\section{Fluorescent in Situ Hybridization (FISH)}

FISH assays were carried out to detect either the loss of chromosome $3 \mathrm{p}$ and chromosome $\mathrm{Y}$ or gain of chromosome 7 and 17. Tissue sections were cut from the TMA blocks and deparaffinized. The assays were done using a $V H L /$ cen 3 probe (ZytoLight ${ }^{\circledR}$ SPEC $V H L / C E N 3$ Dual Color Probe, Zytovision,) and centromeric probes for chromosome 7, 17 and Y (Cytocell) according to the manufacturer's instructions. Slides were digitalized by using a Pannoramic Midi slide scanner (3DHISTECH), and reactions were evaluated using a Pannoramic Viewer (3DHISTECH) in the following way. Fifty tumor cells from each case were examined and were compared with the same number of cells of the peritumoral tissue, which served as an internal control. The cutoff values of chromosomal gain and/or loss were set at the mean $\pm 3 \mathrm{SD}$ of the corresponding control values, as done in previous studies [5]. The analysis of $3 p$ deletion was also performed based on a published method [15].

\section{VHL Gene Sequence Analysis and VHL Gene Promoter Hypermethylation}

A PCR-based amplification method was used for $V H L$ gene mutation analysis as earlier described [16]. The VHL exons were amplified via specific primer pairs (Supplementary Table 2). In the case of pathological mutation, the apparently tumor-free renal tissue was analyzed as well. A GenomeLAB DTCS - Quick Start Kit (Beckman Coulter) was used for DNA sequencing. The latter was carried out according to the manufacturer's instructions using the GenomeLab GeXP Genetic Analysis System (Beckman Coulter). The methylation status of $V H L$ gene promoter region was determined using the methylation-specific PCR method. The extracted genomic DNA was modified using the EpiJET Bisulfite Conversion Kit (ThermoFischer Scientific), and followed by PCR-based amplification with methylation-specific primer pairs (Supplementary Table 3). The methylation status (nonmethylated, methylated) was determined by gel electrophoresis of the PCR products, as reported previously [17].

\section{Criteria for Diagnosing a Tumor as CCPRCC}

The diagnosis of CCPRCC was made if the above-mentioned morphology together with characteristic immunophenotype (CK7- and CA9-positivity, negative CD10 or at most focal CD10-positivity, negative TFE3 and TFEB stainings), along with the lack of genetic alterations indicating CCRCC (3p deletion, VHL mutation, VHL promoter hypermethylation), and PRCC (7 and 17 trisomy, loss of Y) were detected. Tumors with the same morphology, CK7 and CA9 coexpression, but with diffuse CD10-positivity or with altered VHL status were classed as CCRCC.

\section{Results}

Using the inclusion criteria, we retrieved 31 samples. All tumors coexpressed CK7 and CA9. The TFE3 and TFEB reactions were uniformly negative; and the CD10 and the AMACR reactions were negative in 27 and 30 cases, respectively. The FISH assays for papillary RCC, available in 27 cases, and deletion of chromosome $3 \mathrm{p}$, available in 29 cases, yielded negative results. The histomorphology, the results for 
VHL mutation and VHL methylation testing, and the immunophenotype confirmed 21 cases as CCPRCC and 10 cases as CCRCC. The principal characteristics of the two subsets are summarized in Tables 1 and 2.

\section{Features of CCPRCCs}

Here, 21 tumors were examined, and the specimens were obtained from 12 females and 9 males. The mean age was 60 years (with range 28 to 84 years). Partial nephrectomy was performed in 4 patients and radical nephrectomy in 17 patients; and one tumor developed in a transplanted kidney. Twenty cases were incidental findings of imaging performed for non-urological symptoms.

\section{Gross Findings}

All the tumors were solitary, and the mean size was $23 \mathrm{~mm}$ (with range 6 to $65 \mathrm{~mm}$ ). Cystic change was present in 12 samples; and multilocular cystic mass existed in cases 7 and 15. The tumorous parenchyma was grey-white to yellowbrown, occasionally with small hemorrhagic foci.

\section{Microscopic Findings}

Each tumor was circumscribed, and at least one thin fibrous, or fibromuscular capsule was present, except in one case. The capsule was thick $(400-800 \mu \mathrm{m})$ and contained smooth muscle in 13 tumors. A minimal infiltration of renal sinus fat was observed in Case 3 (Fig. 1a, b). Vascular invasion was not detected in any of the cases examined. The dominant growth pattern was tubulo-acinar (15 tumors), with cyst formation in a continuum from microscopic to macroscopic cystic spaces in 12 samples. Also, a papillary architecture was observed in 14 tumors and was detected mainly focally, except in one case where it was predominantly seen. Solid areas with compact cell nests and trabeculae were seen in 11 samples, and it was mostly made up of a small proportion of the tumorous parenchyma. Foamy macrophages, psammoma bodies and necrosis were absent. Although the clear cell phenotype was a distinctive feature, the tumor cells displayed various cytological characteristics. Most of them were cuboidal or columnar, but flattened forms in cysts, as well as elongated cells arranged focally in a fascicular pattern in solid areas were also encountered. Some tumor cells - especially in solid areas - had eosinophilic cytoplasm. Prominent nucleoli were not present. The linear arrangement of nuclei together with its orientation away from the basement membrane was observed in 16 tumors (from a minimal to an extensive presence). Mitotic figures were occasionally seen. Stromal smooth muscle was found in 18 cases including two samples with abundant myomatous stroma (cases 1 and 7).

\section{Immunohistochemical and Molecular Profile}

All tumors exhibited a strong and diffuse CK7 expression. Immunoreaction for CA9 resulted in diffuse staining in 17 tumor samples, and focal staining in 4 tumor samples. The "cup-shaped" pattern was detected in 17 cases, visible mainly in the tubular and cystic areas. Focal CD10-positivity was found in 2 samples. Weak granular, diffuse AMACRpositivity was noted in Case 14 .

The mutation status of the $V H L$ gene was investigated in 11 samples, and in Case 12, single nucleotide polymorphism (SNP) in untranslated region (UTR) was found. The VHL gene promoter hypermethylation status was analyzed in 16 samples; and none of these harbored promoter region hypermethylation.

\section{Follow-up}

The median time was 52.5 months (with range 1 to 184 months). Three patients did not have a follow-up, and two patients died in non-cancer-related causes. No evidence of tumor progression and recurrence was documented in the data of the 18 surviving patients.

\section{Features of CCRCCs Mimicking CCPRCC}

In this group, we analyzed 10 cases, and the mean age was 51 years (with range 37 to 69 years) with 5 female and 5 male patients. Half of the cases were treated via partial nephrectomy. Tumor-related symptoms were registered in two patients. In Case 23, a CCRCC (CA9 and CD10: diffusely positive; CK7 negative) was resected from the contralateral kidney two months after the first surgery. And in Case 24, a metastatic perihilar lymph node was removed together with the tumorous kidney (Fig. 1c-f).

\section{Gross Findings}

The mean size of the tumors was $29 \mathrm{~mm}$ (with range 15 to 50 $\mathrm{mm})$. Cystic change was noticed almost in all cases (9/10). The cut surface was indistinguishable from those seen in CCPRCC.

\section{Microscopic Findings}

A capsule containing smooth muscle was present in 6 cases. The predominant growth pattern was tubulo-acinar $(5 / 10)$, followed by cystic (2/10), papillary (1/10) and solid (1/10). In Case 29, the distribution of tubulo-acinar, papillary and cystic pattern was the same. The tumors were composed of clear cytoplasm cells with focal eosinophilic granulations. Also, an apical linear nuclear arrangement was noted in 6 cases, and 2 cases contained a smooth muscle rich stroma. The infiltration of the renal vein, renal sinus and perinephric fat tissue was not observed. 
Table 1 Clinicopathological features of the cases examined

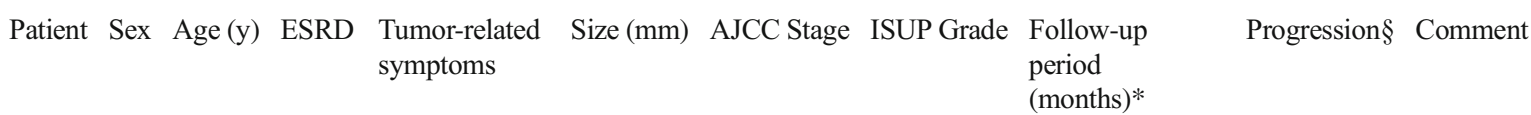

\begin{tabular}{|c|c|c|c|c|c|c|c|c|c|c|}
\hline \multicolumn{11}{|c|}{ Clear cell papillary RCC } \\
\hline 1 & M & 68 & No & No & 21 & T1aNxMx & 1 & 31 & No & \\
\hline 2 & M & 57 & No & No & 20 & T1aNxMx & 2 & 35 & No & \\
\hline 3 & M & 64 & No & No & 30 & T3aNxMx & 2 & NA & ND & Sinus fat tissue infiltration \\
\hline 4 & $\mathrm{~F}$ & 68 & No & No & 30 & T1aNxMx & 1 & 12 & No & \\
\hline 5 & M & 84 & ESRD & No & 10 & T1aNxMx & 1 & 1 & No & \\
\hline 6 & $\mathrm{~F}$ & 63 & No & No & 8 & T1aNxMx & 2 & 46 & No & Ipsilateral oncocytoma \\
\hline 7 & $\mathrm{~F}$ & 81 & No & No & 25 & T1aNxMx & 1 & 113 & No & \\
\hline 8 & $\mathrm{~F}$ & 78 & No & No & 20 & T1aNxMx & 1 & 184 & No & \\
\hline 9 & M & 56 & ACKD & No & 10 & T1aNxMx & 1 & 85 & No & \\
\hline 10 & M & 66 & No & No & 11 & T1aNxMx & 1 & 3 & No & \\
\hline 11 & $\mathrm{~F}$ & 49 & No & No & 38 & T1aNxMx & 1 & 10 & No & \\
\hline 12 & M & 75 & No & No & 65 & T1bNxMx & 2 & 80 & No & \\
\hline 13 & $\mathrm{~F}$ & 52 & No & No & 25 & T1aNxMx & 2 & 158 & No & \\
\hline 14 & M & 32 & No & No & 8 & T1aNxMx & 1 & 101 & No & \\
\hline 15 & $\mathrm{~F}$ & 57 & No & No & 6 & T1aNxMx & 1 & NA & ND & \\
\hline 16 & $\mathrm{~F}$ & 30 & ESRD & No & 8 & T1aNxMx & 1 & 86 & No & \\
\hline 17 & $\mathrm{~F}$ & 60 & No & Abdominal pain & 22 & T1aNxMx & 1 & 3 & No & \\
\hline 18 & M & 76 & No & No & 10 & T1aN0Mx & 1 & 62 & No & $\begin{array}{l}\text { Ipsilateral angiomyolipoma } \\
\text { and papillary adenomas }\end{array}$ \\
\hline 19 & $\mathrm{~F}$ & 69 & No & No & 13 & T1aNxMx & 1 & 8 & No & \\
\hline 20 & $\mathrm{~F}$ & 28 & ESRD & No & 20 & T1aNxMx & 2 & 59 & No & Tumor in a graft kidney \\
\hline 21 & $\mathrm{~F}$ & 56 & No & No & 30 & T1aNxMx & 1 & NA & ND & \\
\hline \multicolumn{11}{|c|}{ Clear cell RCC } \\
\hline 22 & $\mathrm{~F}$ & 41 & No & No & 20 & T1aNxMx & 1 & 26 & No & \\
\hline 23 & $\mathrm{~F}$ & 44 & No & No & 50 & T1bN1Mx & 1 & 36 & No & Lymph node metastasis \\
\hline 24 & M & 37 & No & Hematuria & 37 & T1aNxMx & 1 & 67 & No & $\begin{array}{l}\text { Contralateral clear cell RCC } \\
\text { two months later }\end{array}$ \\
\hline 25 & M & 47 & $\mathrm{ACKD}$ & No & 19 & T1aNxMx & 1 & 12 & No & \\
\hline 26 & $\mathrm{~F}$ & 53 & No & No & 30 & T1aNxMx & 1 & 19 & No & \\
\hline 27 & $\mathrm{~F}$ & 69 & No & No & 24 & T1aNxMx & 2 & 37 & No & \\
\hline 28 & M & 69 & No & Lumbar pain & 15 & T1aNxMx & 1 & 100 & No & Ipsilateral papillary adenoma \\
\hline 29 & M & 40 & No & No & 30 & T1aNxMx & 1 & 10 & No & \\
\hline 30 & $\mathrm{~F}$ & 51 & No & No & 40 & T1aNxMx & 1 & 3 & No & \\
\hline 31 & M & 61 & No & No & 25 & T1aNxMx & 2 & 6 & No & \\
\hline
\end{tabular}

*Follow-up, determined from the surgery to the last follow-up; §Progression, assessed by radiological and/or autopsy data $M$ male; $F$ female; ESRD end-stage renal disease; $A C K D$ acquired cystic kidney disease; $N A$ not available; $N D$ no data

\section{Immunohistochemical and Molecular Profile}

There was a coexpression of CK7 in a diffuse fashion and CA9 in a diffuse ( 8 cases) or focal fashion (2 cases). The cup-shaped distribution of CA9 was present in 6 cases. Diffuse CD10-positivity was observed in cases 23 and 24.

The VHL gene mutation status was analyzed in 9 samples, and in cases 22,23 and 31 a pathogenic mutation was identified that was not present in the tumor-free renal parenchyma (Fig. 2). The sequencing revealed an
SNP without any clinical significance in Case 24. The remaining 5 tumors analyzed harbored no genetic change. Also, the VHL gene promoter hypermethylation was tested in 8 cases, and 7 of them possessed promoter region hypermethylation.

\section{Follow-up}

All the cases had follow-up data with a median of 31.6 months (with range 3 to 100 months). None of them experienced any recurrence and cancer-related death. 
Table 2 Morphological, immunohistochemical, and molecular characteristics of the cases examined.

\begin{tabular}{|c|c|c|c|c|c|c|c|c|c|c|c|c|c|c|c|}
\hline \multirow[t]{2}{*}{ Patient } & \multicolumn{4}{|c|}{ Architecture of tumor volume (\%) } & \multicolumn{5}{|c|}{ Immune profile $(\%)$} & \multicolumn{6}{|c|}{ Molecular characteristics } \\
\hline & Tubular Papillary & Cystic & Solid & $\mathrm{LiN}$ & CK7 & CA9 & CA9 cup-shaped & CD10 & AMACR & +7 & +17 & Y & & VHL mut & $V H L$ met \\
\hline
\end{tabular}

Clear cell papillary RCC

$\begin{array}{lllllllll}1 & 90 & - & - & 10 & \text { No } & \text { Diff } & \text { Diff } & \text { Yes } \\ 2 & 88 & 2 & - & 10 & \text { Yes } & \text { Diff } & \text { Diff } & \text { Yes } \\ 3 & 95 & - & - & 5 & \text { Yes } & \text { Diff } & \text { Diff } & \text { Yes } \\ 4 & 59 & 1 & 20 & 20 & \text { Yes } & \text { Diff } & \text { Diff } & \text { Yes } \\ 5 & 100 & - & - & - & \text { Yes } & \text { Diff } & \text { Diff } & \text { Yes } \\ 6 & 95 & 5 & - & - & \text { Yes } & \text { Diff } & \text { Diff } & \text { Yes } \\ 7 & 44 & 5 & 50 & 1 & \text { No } & \text { Diff } & \text { Diff } & \text { Yes } \\ 8 & 50 & 50 & - & - & \text { Yes } & \text { Diff } & \text { Diff } & \text { Yes } \\ 9 & 80 & 10 & - & 10 & \text { No } & \text { Diff } & \text { Diff } & \text { Yes } \\ 10 & 95 & 5 & - & - & \text { Yes } & \text { Diff } & \text { Diff } & \text { Yes } \\ 11 & 50 & 40 & 10 & - & \text { Yes } & \text { Diff } & \text { Diff } & \text { Yes } \\ 12 & 50 & - & 50 & - & \text { Yes } & \text { Diff } & \text { Diff } & \text { Yes } \\ 13 & - & 80 & 20 & - & \text { No } & \text { Diff } & \text { Diff } & \text { Yes } \\ 14 & 80 & 10 & 10 & - & \text { Yes } & \text { Diff } & \text { Diff } & \text { Yes } \\ 15 & - & 20 & 80 & - & \text { Yes } & \text { Diff } & \text { Diff } & \text { No } \\ 16 & 95 & - & - & 5 & \text { Yes } & \text { Diff } & \text { Diff } & \text { No } \\ 17 & 50 & 20 & 30 & - & \text { No } & \text { Diff } & \text { Diff } & \text { No } \\ 18 & 90 & - & 5 & 5 & \text { Yes } & \text { Diff } & \text { Foc } & \text { Yes } \\ 19 & 45 & 1 & 50 & 4 & \text { Yes } & \text { Diff } & \text { Foc } & \text { Yes } \\ 20 & 89 & - & 1 & 10 & \text { Yes } & \text { Diff } & \text { Foc } & \text { Yes } \\ 21 & 85 & 1 & 5 & 10 & \text { Yes } & \text { Diff } & \text { Foc } & \text { No }\end{array}$

$\begin{array}{llllllll}\text { Neg } & \text { Neg } & - & - & - & - & \text { wt } & \text { ua } \\ \text { Foc } & \text { Neg } & - & - & - & - & \text { wt } & - \\ \text { Neg } & \text { Neg } & \text { nd } & \text { nd } & \text { nd } & \text { nd } & \text { nd } & \text { nd } \\ \text { Neg } & \text { Neg } & - & - & & - & \text { wt } & - \\ \text { Neg } & \text { Neg } & - & \text { nd } & - & - & \text { nd } & \text { nd } \\ \text { Foc } & \text { Neg } & - & - & & - & \text { wt } & - \\ \text { Neg } & \text { Neg } & - & - & & - & \text { wt } & - \\ \text { Neg } & \text { Neg } & - & - & & - & \text { ua } & - \\ \text { Neg } & \text { Neg } & - & - & - & - & \text { wt } & - \\ \text { Neg } & \text { Neg } & - & - & - & - & \text { wt } & - \\ \text { Neg } & \text { Neg } & - & - & & - & \text { wt } & - \\ \text { Neg } & \text { Neg } & - & - & - & - & 5 \text { JTR } S N P^{\#} & - \\ \text { Neg } & \text { Neg } & - & - & & - & \text { ua } & - \\ \text { Neg } & \text { Poz } & - & - & - & - & \text { wt } & - \\ \text { Neg } & \text { Neg } & - & - & & - & \text { ua } & \text { nd } \\ \text { Neg } & \text { Neg } & - & - & & & \text { ua } & \text { nd } \\ \text { Neg } & \text { Neg } & - & - & & - & \text { wt } & - \\ \text { Neg } & \text { Neg } & \text { nd } & \text { nd } & \text { nd } & \text { nd } & \text { nd } & - \\ \text { Neg } & \text { Neg } & - & - & - & \text { nd } & - \\ \text { Neg } & \text { Neg } & - & - & - & \text { ua } & - \\ \text { Neg } & \text { Neg } & - & - & - & \text { ua } & -\end{array}$

Clear cell RCC

$\begin{array}{lllllllll}22 & 50 & 5 & 35 & 10 & \text { Yes } & \text { Diff } & \text { Diff } & \text { Yes } \\ 23 & 50 & 20 & 30 & - & \text { Yes } & \text { Diff } & \text { Diff } & \text { Yes } \\ 24 & 10 & 50 & 20 & 20 & \text { No } & \text { Diff } & \text { Diff } & \text { No } \\ 25 & 80 & 10 & 10 & - & \text { No } & \text { Diff } & \text { Diff } & \text { Yes } \\ 26 & 95 & 1 & - & 4 & \text { Yes } & \text { Diff } & \text { Diff } & \text { Yes } \\ 27 & 20 & 10 & 70 & - & \text { Yes } & \text { Diff } & \text { Diff } & \text { Yes } \\ 28 & 40 & - & 60 & - & \text { Yes } & \text { Diff } & \text { Diff } & \text { Yes } \\ 29 & 20 & 40 & 40 & - & \text { Yes } & \text { Diff } & \text { Diff } & \text { No } \\ 30 & 30 & - & 20 & 50 & \text { No } & \text { Diff } & \text { Foc } & \text { No } \\ 31 & 90 & - & - & 10 & \text { Yes } & \text { Diff } & \text { Foc } & \text { No }\end{array}$

$\begin{array}{llllllll}\text { Neg } & \text { Neg } & - & - & & - & \text { mut }^{a} & + \\ \text { Diff } & \text { Neg } & \text { nd } & \text { nd } & & - & \text { mut } & \\ \text { Diff } & \text { Neg } & - & - & - & - & 5^{\prime} U_{R} \text { SNP } & \text { nd } \\ \text { Neg } & \text { Neg } & - & - & - & - & \text { wt } & + \\ \text { Neg } & \text { Neg } & - & - & & - & \text { wt } & + \\ \text { Neg } & \text { Neg } & - & - & & - & \text { wt } & + \\ \text { Neg } & \text { Neg } & - & - & - & - & \text { ua } & + \\ \text { Neg } & \text { Neg } & - & - & - & - & \text { wt } & + \\ \text { Neg } & \text { Neg } & - & - & & - & \text { wt } & + \\ \text { Neg } & \text { Neg } & - & - & - & - & \text { mut } & \text { nd }\end{array}$

LiN linear nuclear arrangement from basement membrane; +7 and +17 trisomy of chromosome 7 and 17, respectively; $-Y$ deletion of chromosome $\mathrm{Y} ;-3 p$ deletion of chromosome 3p; VHL mut, von Hippel-Lindau gene mutation status; VHL met, von Hippel-Lindau gene methylation status; $n d$ not determined; $w t$ wild type; $u a$ unsuccessful analysis; 5'UTR SNP single nucleotide polymorphism in 5' untranslated region; diff diffuse; foc focal; neg negative (less than or equal to $10 \%$ )

${ }^{\S}$ weak granular positivity; ${ }^{\#}$ exon 3 could not be amplified; ${ }^{\text {II }}$ exon1b could not be amplified; ${ }^{\text {a }}$ c.221T >A $/$ p.V74N; ${ }^{\text {b }}$ c.625C $>$ T/p.G209*; ${ }^{\text {c }}$ c.354_ 361delCTTCAGAGinsT

\section{Discussion}

The WHO classification of RCCs defines the subsets via a synthesis of histopathological, immunohistochemical, and genetic data [1]. In the current study, we focused on the discrimination of CCPRCC from other tumor types by applying the well-known immunohistochemical markers supplemented with a molecular analysis that seeks to find chromosomal abberations and VHL abnormalities (including mutations as well as methylation analysis). We made a formal diagnosis of CCPRCC when both the immunohistochemical and the genetic tests were in complete accordance with the histology.

All the RCC subtypes with clear cell phenotype (i.e. TFE3 or TFEB translocation RCCs, TCEB1-mutated RCC [18], 

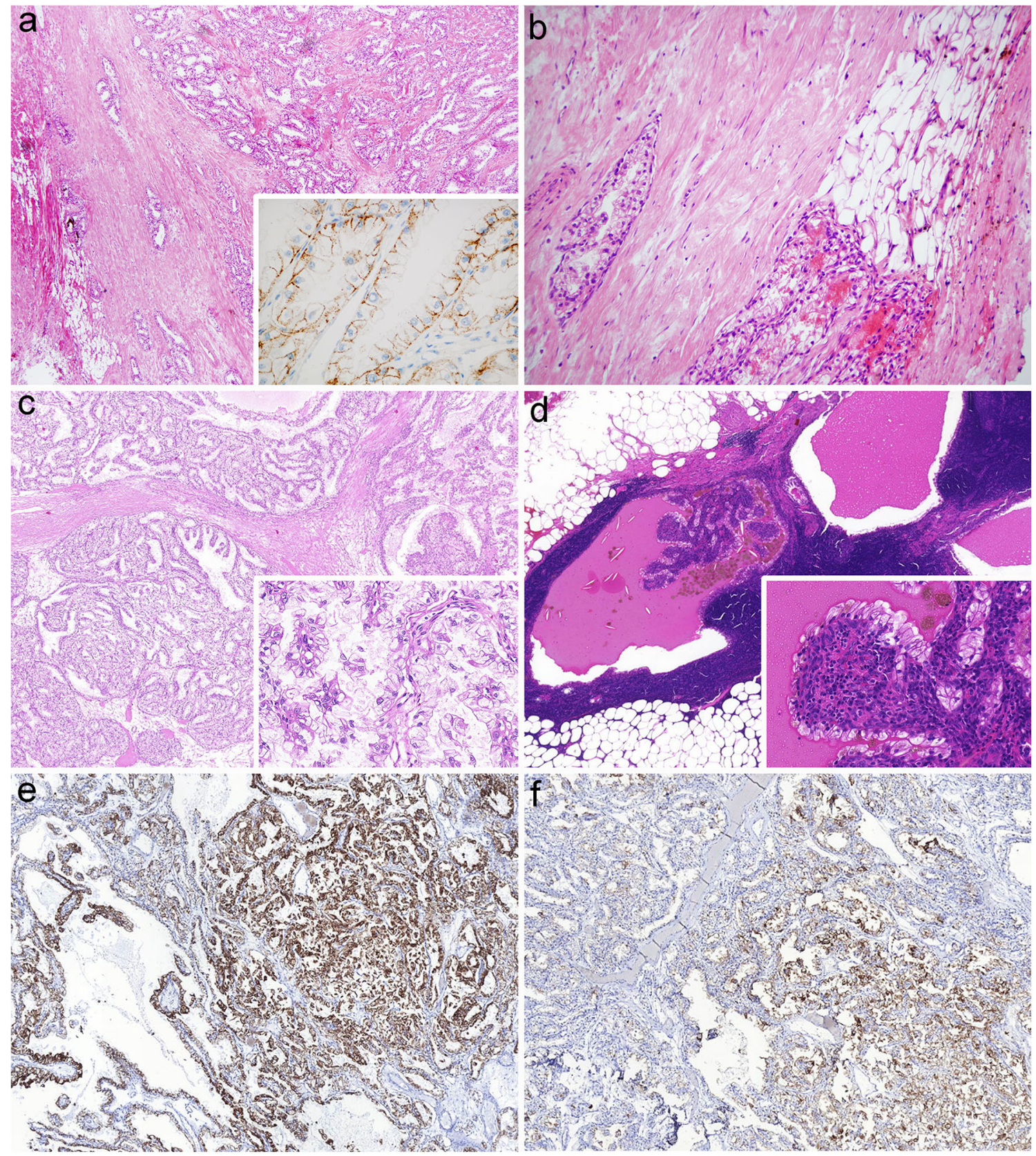

Fig. 1 a-b Case 3 with sinus fat invasion The tumor showed a branching tubular pattern and an immunophenotype characteristic for CCPRCC (basolateral CA9 reaction in the insert) (a). Superficial infiltration of sinus fat was seen (b). Figure 1 c-f Case 23 with lymph node metastasis The tumor displayed the morphological features of CCPRCC, partly with papillary architecture (c). The lymph node

RCC with 8p monosomy [19], RCC with prominent smooth muscle stroma (RCCSMS) [20-25] and RCC associated with von Hippel-Lindau syndrome) can exhibit a CCPRCC-like histomorphology [26, 27], but CCRCC cases pose the biggest difficulty because this tumor type is the most common and it also has some morphological similarities. CCRCCs are viewed as tumors that are $\mathrm{CA} 9+$ and $\mathrm{CD} 10+$, and display no more than a focal CK 7 positivity. In contrast, the metastasis was mainly cystic; with some papillary infoldings (insert in figure d) (d). The tumor exhibited a diffuse CK7 positivity (e), but extensive CD10 staining was also observed (f). The latter, together with the $V H L$ gene mutation detected in this tumor were not consistent with the diagnosis of CCPRCC

immunophenotype of CCPRCCs is CK7+, CA9+, and CD10-. Perhaps diffuse and strong CK7 positivity is considered the most important and an obligatory diagnostic criterion for CCPRCC. Nevertheless, the lack of a widespread CD10 reaction is also required.

We performed our case selection based on histological features suggestive of CCPRCC, and all the tumors displayed diffuse CK7 staining. In two of them, however, 

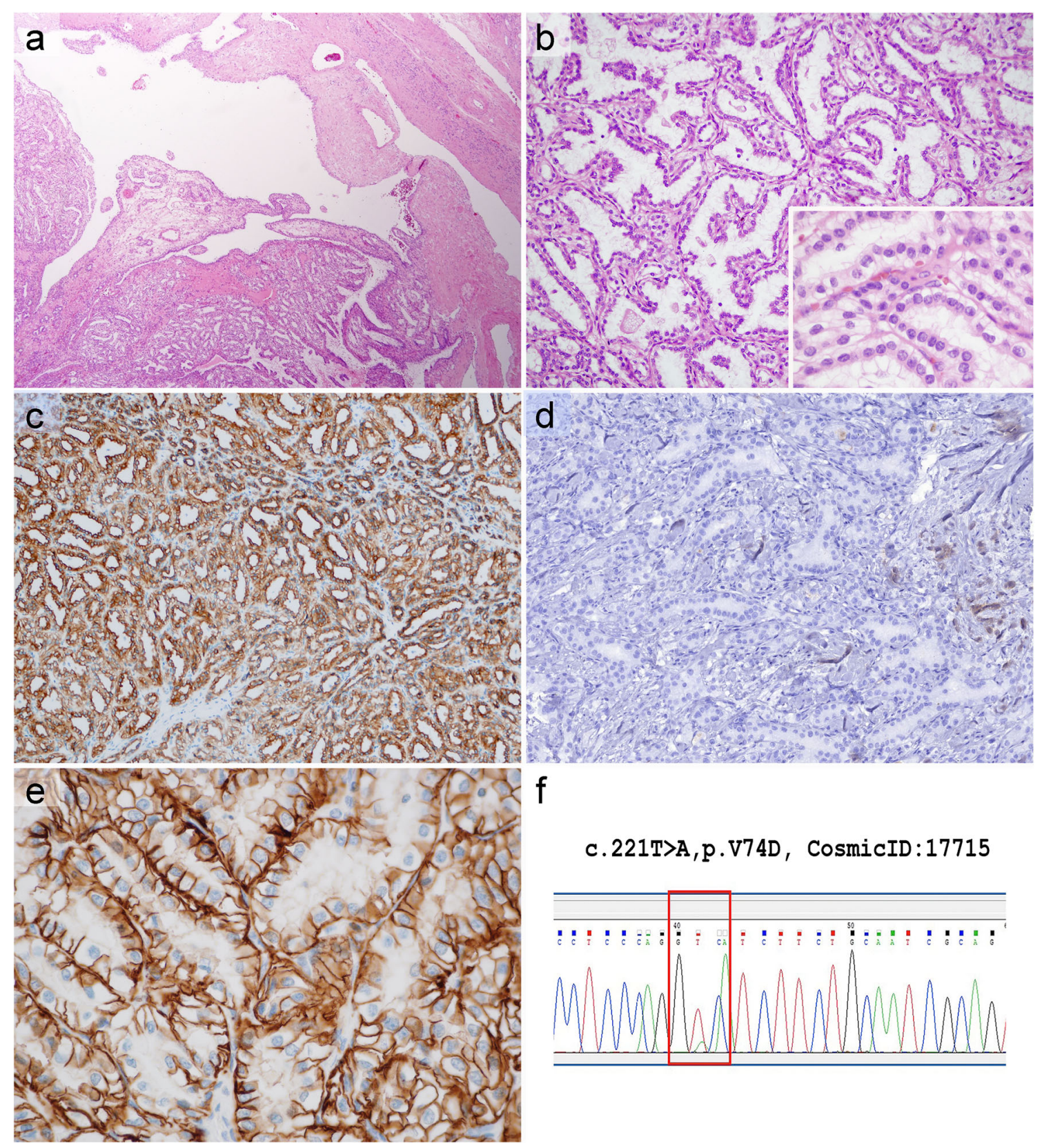

Fig. 2 Case 22 exhibiting morphology and immunophenotype completely consistent with $\mathrm{CCPRCC}$, but containing a $\mathrm{VHL}$ gene mutation. The tumor had a thick fibromyomatous capsule and it was composed of both solid and cystic areas (a). Branching tubular

CD10 positivity was also diffuse, which supported our diagnosis of CCRCC. In another subset of our cases, the morphology and immunophenotype wholly favoured the diagnosis of CCPRCC; however, either VHL mutation (3 cases) or VHL promoter hypermethylation ( 7 cases) was present. We accepted the view of Hes et al. who recommended not classifying cases with any $V H L$ gene abnormality as CCPRCC [28]. Based on their approach, our tumors with altered VHL status were classified as CCRCC. architectural pattern was the most characteristic (b). The tumor cells were diffusely positive for CK7 (c); and negative for CD10 (d). CA9 immunoreaction also resulted in a diffuse staining with a basolateral pattern (e). VHL gene mutation was detected by direct sequencing (f)

After performing an immunohistochemical and molecular analysis, our selected cases with histology of CCPRCCs were subdivided into two groups. These are CCPRCCs (21 cases), and CCRCCs with diffuse CK7 positivity (10 cases).

\section{Features of CCPRCC Cases}

The characteristic pattern of these tumors was branching tubulo-acinar that was commonly accompanied by cyst formation. Papillary areas, however, were detected as a minor 
component except in three cases. As similar findings on the extent of papillarity were obtained by Aydin et al. [5] and by Williamson et al. [29], we conclude that CCPRCC with predominant papillarity probably occurs quite rarely. Therefore, the WHO designation of this entity seems inaccurate, and the appellation "tubulopapillary" would perhaps be more apt, as was suggested by Aydin et al [5].

Linear nuclear arrangement away from the basement membrane is regarded as characteristic for CCPRCC [30]. Actually, 16/21 of CCPRCCs and 7/10 CCRCCs with diffuse CK7-positivity harbored this phenomenon (from a minimal to extensive presence). Dhakal et al. examined 37 tumors with a morphologic overlap between CCPRCC and CCRCC features, and linear nuclear arrangement was not the exclusive feature of cases classified as CCPRCC [31]. In another series of CCPRCC, Williamson at al. noticed linear nuclear arrangement only in 24/55 cases [32]. These findings suggest that linear nuclear arrangement is an overemphasized phenomenon, since its absence does not exclude the possible diagnosis of CCPRCC, and its presence does not necessarily support the diagnosis of CCPRCC.

The cup-shaped expression of CA9 was not uniformly present in our series. A diffuse cup-shaped expression was observed in 17/21 samples, while a dominant box-shaped staining with a focal cup-shaped expression was noted in 4/ 21 samples. Upon reviewing the literature, a cup-shaped expression involving $50 \%$ of tumor cells was reported by Rohan et al. in 3 out of their 9 cases [6]; and Dhakal et al. noted a cuplike expression of CA9 in 74\% of their cases [31]; and Aydin et al. did not mention this feature at all in their 36 cases [5]. Since in our experience the cup-shaped staining pattern cannot be discerned unambiguously in solid areas, the absence of cup-shaped expression should be interpreted with caution when making a concrete diagnosis of CCPRCC for a specific case. A diffuse and weak granular AMACR-positivity was seen in one case. We reviewed the immunoprofile of the published CCPRCC cases and, albeit rarely, AMACR-positivity was reported [5, 6, 11, 29, 32-34]; hence if it is present, it does not necessarily contradict the diagnosis of CCPRCC. Focal CD10-positivity was encountered in two, otherwise completely typical CCPRCC, and VHL gene abnormalities were not present in these samples. The focal extent of CD10 expression may indicate the possibility of RAT, because a lack of a cystic component viewed microscopically, and the triple coexpression of CK7, CA9 and a certain degree of CD10 were noted in a series of RCC cases classified as RAT [35].

Our CCPRCC group comprised 19 pT1a, 1 pT1b and 1 pT3a cases, respectively. To our knowledge, ours is the first reported case with infiltration outside of the kidney parenchyma. Also, in Case 20 the tumor developed in a transplanted kidney. In a recently published review, Dhakal at al. [36] summarized the findings of 24 articles that reported tumors in transplanted kidneys, but among the 48 tumors described, not one was CCPRCC. Coexisting benign tumors and CCPRCC were observed in two cases. Actually, in Case 6 the oncocytoma had been detected clinically, and during the grossing CCPRCC was discovered. All of our CCPRCC cases had an excellent clinical outcome, reinforcing the view that the carcinoma designation might be exaggerated $[14,37,38]$.

\section{Features of CCRCCs with Diffuse CK7-Positivity}

A series of CCRCC with diffuse CK7-posivity was published a decade ago by Mai et al [39]. Similar to our experiences, these samples were small-sized, and a non-metastatic course was recorded over a mean of a 3-year follow-up; and diffuse CK7positivity was viewed as the indicator of indolent behaviour [40].

Our results provide further clinicopathologic data on this rare subset of CCRCC. Accordingly, neither 3p deletion, nor other chromosomal anomalies were present. The VHL gene sequence analysis revealed pathologic mutations in cases 22 , 23 and 31. Since VHL mutations were not identified in the non-tumorous renal tissue, the possibility of VHL-diseaseassociated CCRCC was excluded.

In seven samples, the histological and immunphenotypic data favoured the diagnosis of CCPRCC; however, the presence of the $V H L$ gene promoter hypermethylation abnormality leads us to place these samples into the CCRCC group. In the study of Herman et al. on silecing of the VHL gene by DNA methylation, the hypermethylation of a $\mathrm{CpG}$ island in the 5, region was noted in 5 samples out of 26 CCRCCs [16]. Four of these had lost one copy of $V H L$, while one retained two heavily methylated alleles. The latter observation indicated
Table 3 Overlapping and discriminating features of CCRCCs and CCPRCCs. As we accepted the view of Hes et al. [18] that VHL gene alteration is not compatible with the diagnosis of CCPRCC, altered $V H L$ status was found as the most reliable discriminating feature between CCRCCs and CCPRCCs in our cohort

\begin{tabular}{lllllll}
\hline $\begin{array}{l}\text { Tubulopapillary } \\
\text { architecture }\end{array}$ & $\begin{array}{l}\text { Subnuclear } \\
\text { vacuolization }\end{array}$ & $\begin{array}{l}\text { Stromal } \\
\text { SM }\end{array}$ & $\begin{array}{l}\text { Diffuse } \\
\text { CK7+ }\end{array}$ & $\begin{array}{l}\text { Diffuse } \\
\text { CD10+ }\end{array}$ & $\begin{array}{l}\text { CA9 cup- } \\
\text { shaped }\end{array}$ & $\begin{array}{l}\text { VHL } \\
3 p\end{array}$ \\
mut & $\begin{array}{l}V H L \\
\text { met }\end{array}$ \\
\hline CCCRCC $+/-$ & $+/-$ & $+/-$ & $+/-$ & $+/-$ & $+/-$ & $+/-$ \\
CCCPRCC + & $+/-$ & $+/-$ & + & - & $+/-$ & - \\
\hline
\end{tabular}

SM smooth muscle; mut mutation; met hypermethylaiton 
that hypermethylation may inactivate the $V H L$ gene even when both wild-type alleles are retained [16]. In our analysis, hypermethylation was noted in seven cases; moreover coexisting $V H L$ gene mutation and methylation was seen in Case 22. After a search for methylation data, only 2 tumors analyzed were found in the literature out of 400 or so CCPRCCs [5, 14]. Methylation analyses performed by others in the future may validate our assumption that a $V H L$ promoter hypermethylation is definitely not compatible with the diagnosis of CCPRCC. In Case 24 (and in Case 12 in the CCPRCC group) an SNP was observed in the 5' UTR region, a finding treated as insignificant, because the nucleotide change did not induce any amino acid change as well. Interestingly, in 8 cases the histological and immunphenotypic data were entirely consistent with the histopathological diagnosis of CCPRCC, but the presence of VHL abnormalities led us to place these samples into the group of low-grade CCRCC with CK7 immunoreactivity and no $3 p$ loss. Every case was in the pT1 stage, and there was no progression or recurrence.

In summary, in our study the immunophenotype and the genetic profile of 31 RCCs composed of clear cells, low-grade nuclei and a tubulopapillary architecture were investigated retrospectively. Twenty-one cases were classified as CCPRCC (CK7+, CA9+; -3p absent, VHL abnormality not present) and 10 as CCRCC with diffuse CK7-positivity (CK7+, CA9+; -3p absent, VHL abnormality present). Based on our findings, the following conclusions can be drawn. First, CCPRCCs rarely exhibit a predominant papillary architecture, hence their name is misleading. Second, a linear nuclear arrangement away from the basement membrane and cup-like CA9 positivity are not obligatory features. Third, the evidence for their malignant potential is still subject of debate. Fourth, RCCs with CCPRCC morphology, diffuse CK7 positivtiy, and with an altered $V H L$ status (mutation, or promoter hypermethylation) do exist; and these tumors can be interpreted as CCRCC with diffuse $\mathrm{CK} 7$ positivity, and they can be definitely differentiated from CCPRCCs only by carrying out molecular tests for the VHL status. And last but, not least the biological behavior of both CCPRCCs and CCRCCs with diffuse CK7 positivity seems to be indolent with a favorable clinical outcome. Overlapping and discriminating features of CCPRCCs and CCRCCs are summarized in Table 3.

Funding Open access funding provided by Semmelweis University (SE). This study was funded by internal sources of the institutions (2nd Department of Pathology and 1st Department of Pathology and Experimental Cancer Research, Semmelweis University, Budapest, Hungary; Department of Pathology, University of Szeged, Szeged, Hungary). No grants were used.

\section{Compliance with Ethical Standards}

Conflict of interest The authors declare that they have no conflict of interest.
Ethical approval The study was ethically approved by the Medical Research Council of Hungary (174894/2017/EKU). The renal carcinoma cases were retrospectively selected from the archives of the pathological institutions and informed consent was not obtained.

Open Access This article is distributed under the terms of the Creative Commons Attribution 4.0 International License (http:// creativecommons.org/licenses/by/4.0/), which permits unrestricted use, distribution, and reproduction in any medium, provided you give appropriate credit to the original author(s) and the source, provide a link to the Creative Commons license, and indicate if changes were made.

\section{References}

1. Srigley JR, Delahunt B, Eble JN et al (2013) The International Society of Urological Pathology (ISUP) Vancouver Classification of Renal Neoplasia. Am J Surg Pathol 37:1469-1489

2. Moch H, Humphrey PA, Ulbright TM, Reuter VE (2016) WHO Classification of Tumours of the Urinary System and Male Genital Organs. International Agency for Research on Cancer

3. Tickoo SK, dePeralta-Venturina MN, Harik LR et al (2006) Spectrum of epithelial neoplasms in end-stage renal disease: an experience from 66 tumor-bearing kidneys with emphasis on histologic patterns distinct from those in sporadic adult renal neoplasia. Am J Surg Pathol 30:141-153

4. Gobbo S, Eble JN, Grignon DJ et al (2008) Clear cell papillary renal cell carcinoma: a distinct histopathologic and molecular genetic entity. Am J Surg Pathol 32:1239-1245

5. Aydin H, Chen L, Cheng L et al (2010) Clear cell tubulopapillary renal cell carcinoma: a study of 36 distinctive low-grade epithelial tumors of the kidney. Am J Surg Pathol 34:1608-1621

6. Rohan SM, Xiao Y, Liang Y et al (2011) Clear-cell papillary renal cell carcinoma: molecular and immunohistochemical analysis with emphasis on the von Hippel-Lindau gene and hypoxia-inducible factor pathway-related proteins. Mod Pathol 24:1207-1220

7. Ross H, Martignoni G, Argani P (2012) Renal cell carcinoma with clear cell and papillary features. Arch Pathol Lab Med 136:391-399

8. Michal M, Hes O, Havlicek F (2000) Benign renal angiomyoadenomatous tumor: a previously unreported renal tumor. Ann Diagn Pathol 4:311-315

9. Michal M, Hes O, Kuroda N et al (2009) Difference between RAT and clear cell papillary renal cell carcinoma/clear renal cell carcinoma. Virchows Arch. https://doi.org/10.1007/s00428-009-0788-9

10. Deml KF, Schildhaus HU, Compérat E et al (2015) Clear cell papillary renal cell carcinoma and renal angiomyoadenomatous tumor: two variants of a morphologic, immunohistochemical, and genetic distinct entity of renal cell carcinoma. Am J Surg Pathol 39:889901

11. Tickoo SK, Reuter VE (2011) Differential diagnosis of renal tumors with papillary architecture. Adv Anat Pathol 18:120-132

12. Kuroda N, Ohe C, Kawakami F et al (2014) Clear cell papillary renal cell carcinoma: a review. Int J Clin Exp Pathol 7:7312-7318

13. Gobbo S, Eble JN, Maclennan GT et al (2008) Renal cell carcinomas with papillary architecture and clear cell components: the utility of immunohistochemical and cytogenetical analyses in differential diagnosis. Am J Surg Pathol 32:1780-1786

14. Diolombi ML, Cheng L, Argani P et al (2015) Do Clear Cell Papillary Renal Cell Carcinomas Have Malignant Potential? Am J Surg Pathol 39:1621-1634

15. Fallon KB, Palmer CA, Roth KA et al (2004) Prognostic value of $1 \mathrm{p}, 19 \mathrm{q}, 9 \mathrm{p}, 10 \mathrm{q}$, and EGFR-FISH analyses in recurrent oligodendrogliomas. J Neuropathol Exp Neurol 63:314-322 
16. Akanni OE, Ferrari M (2006) Sequencing of Von Hippel-Lindau (VHL) Gene from Genomic DNA for Mutation Detection in Italian Patients. EJIFCC 17:12-16

17. Herman JG, Graff JR, Myohanen S et al (1996) Methylationspecific PCR: a novel PCR assay for methylation status of $\mathrm{CpG}$ islands. Proc Natl Acad Sci USA 93:9821-9826

18. Hakimi AA, Tickoo SK, Jacobsen A et al (2015) TCEB1-mutated renal cell carcinoma: a distinct genomic and morphological subtype. Mod Pathol 28:845-853

19. Lan TT, Keller-Ramey J, Fitzpatrick C et al (2016) Unclassified renal cell carcinoma with tubulopapillary architecture, clear cell phenotype, and chromosome 8 monosomy: a new kid on the block. Virchows Arch 469:81-91

20. Canzonieri V, Volpe R, Gloghini A et al (1993) Mixed renal tumor with carcinomatous and fibroleiomyomatous components, associated with angiomyolipoma in the same kidney. Pathol Res Pract 189:951-956

21. Martignoni G, Brunelli M, Segala D et al (2014) Renal cell carcinoma with smooth muscle stroma lacks chromosome $3 p$ and VHL alterations. Mod Pathol 27:765-774

22. Petersson F, Branzovsky J, Martinek P et al (2014) The leiomyomatous stroma in renal cell carcinomas is polyclonal and not part of the neoplastic process. Virchows Arch 465:89-96

23. Kuhn E, De Anda J, Manoni S et al (2006) Renal cell carcinoma associated with prominent angioleiomyoma-like proliferation: Report of 5 cases and review of the literature. Am J Surg Pathol 30:1372-1381

24. Shannon BA, Cohen RJ, Segal A et al (2009) Clear cell renal cell carcinoma with smooth muscle stroma. Hum Pathol 40:425-429

25. Petersson F, Martinek P, Vanecek T et al (2018) Renal Cell Carcinoma With Leiomyomatous Stroma: A Group of Tumors With Indistinguishable Histopathologic Features, But 2 Distinct Genetic Profiles: Next-Generation Sequencing Analysis of 6 Cases Negative for Aberrations Related to the VHL gene. Appl Immunohistochem Mol Morphol 26:192-197

26. Williamson SR, Zhang S, Eble JN et al (2013) Clear cell papillary renal cell carcinoma-like tumors in patients with von HippelLindau disease are unrelated to sporadic clear cell papillary renal cell carcinoma. Am J Surg Pathol 37:1131-1139

27. Rao P, Monzon F, Jonasch E et al (2014) Clear cell papillary renal cell carcinoma in patients with von Hippel-Lindau syndromeclinicopathological features and comparative genomic analysis of 3 cases. Hum Pathol 45:1966-1972

28. Hes O, Compérat EM, Rioux-Leclercq N (2016) Clear cell papillary renal cell carcinoma, renal angiomyoadenomatous tumor, and renal cell carcinoma with leiomyomatous stroma relationship of 3 types of renal tumors: a review. Ann Diagn Pathol 21:59-64

29. Williamson SR, Eble JN, Cheng L et al (2013) Clear cell papillary renal cell carcinoma: differential diagnosis and extended immunohistochemical profile. Mod Pathol 26:697-708
30. Zhou H, Zheng S, Truong LD et al (2014) Clear cell papillary renal cell carcinoma is the fourth most common histologic type of renal cell carcinoma in 290 consecutive nephrectomies for renal cell carcinoma. Hum Pathol 45:59-64

31. Dhakal HP, McKenney JK, Khor LY et al (2016) Renal Neoplasms With Overlapping Features of Clear Cell Renal Cell Carcinoma and Clear Cell Papillary Renal Cell Carcinoma: A Clinicopathologic Study of 37 Cases From a Single Institution. Am J Surg Pathol 40:141-154

32. Williamson SR, Gupta NS, Eble JN et al (2015) Clear Cell Renal Cell Carcinoma With Borderline Features of Clear Cell Papillary Renal Cell Carcinoma: Combined Morphologic, Immunohistochemical, and Cytogenetic Analysis. Am J Surg Pathol 39:1502-1510

33. Aron M, Chang E, Herrera L et al (2015) Clear Cell-Papillary Renal Cell Carcinoma of the Kidney Not Associated With End-stage Renal Disease Clinicopathologic Correlation With Expanded Immunophenotypic and Molecular Characterization of a Large Cohort With Emphasis on Relationship With Renal Angiomyoadenomatous Tumor. Am J Surg Pathol 39:873-888

34. Alexiev BA, Drachenberg CB (2014) Clear cell papillary renal cell carcinoma: Incidence, morphological features, immunohistochemical profile, and biologic behavior: A single institution study. Pathol Res and Pract 210:234-241

35. Petersson F, Grossmann P, Hora M et al (2013) Renal cell carcinoma with areas mimicking renal angiomyoadenomatous tumor/clear cell papillary renal cell carcinoma. Hum Pathol 44:1412-1420

36. Dhakal P, Giri S, Siwakoti K et al (2017) Renal Cancer in Recipients of Kidney Transplant. Rare Tumors 9:6550

37. Adam J, Couturier J, Molinié V et al (2011) Clear-cell papillary renal cell carcinoma: 24 cases of a distinct low-grade renal tumour and a comparative genomic hybridization array study of seven cases. Histopathology 58:1064-1071

38. Massari F, Ciccarese C, Hes O et al (2018) The Tumor Entity Denominated "clear cell-papillary renal cell carcinoma" According to the WHO 2016 new Classification, have the Clinical Characters of a Renal Cell Adenoma as does Harbor a Benign Outcome. Pathol Oncol Res 24:447-456

39. Mai KT, Kohler DM, Belanger EC et al (2008) Sporadic clear cell renal cell carcinoma with diffuse cytokeratin 7 immunoreactivity. Pathology 40:481-486

40. Mertz KD, Demichelis F, Sboner A et al (2008) Association of cytokeratin 7 and 19 expression with genomic stability and favorable prognosis in clear cell renal cell cancer. Int J Cancer 123:569576

Publisher's Note Springer Nature remains neutral with regard to jurisdictional claims in published maps and institutional affiliations. 